\section{EMBRYRIDDLE}

Aeronautical University

SCHOLARLY COMMONS
Journal of Aviation/Aerospace

Education \& Research

Volume 16

Number 3 JAAER Spring 2007

Article 10

Spring 2007

\title{
The Effects of Pedagogical Paradigms on Aviation Students with Hazardous Attitudes
}

Michael Wetmore

Chien-tsung Lu

William Caldwell

Follow this and additional works at: https://commons.erau.edu/jaaer

\section{Scholarly Commons Citation}

Wetmore, M., Lu, C., \& Caldwell, W. (2007). The Effects of Pedagogical Paradigms on Aviation Students with Hazardous Attitudes. Journal of Aviation/Aerospace Education \& Research, 16(3). https://doi.org/ 10.15394/jaaer.2007.1469

This Article is brought to you for free and open access by the Journals at Scholarly Commons. It has been accepted for inclusion in Journal of Aviation/Aerospace Education \& Research by an authorized administrator of Scholarly Commons. For more information, please contact commons@erau.edu. 


\title{
THE EFFECTS OF PEDAGOGICAL PARADIGMS ON AVITION STUDENTS WTTH HAZARDOUS ATTITUDES
}

\author{
Michael Wetmore, Chien-tsung Lu and William Caldwell
}

\begin{abstract}
Hazardous attitudes can adverselyraffect a pilot's judgment and thus impact the safety of a flight (FAA, 1991). These hazardous attitudes are antiauthority; impulsivity; invulnerability; macho; and, resignation. Wetmore \& Lu (inpress) found hazardous attitudes to be a causal or contributing factor in $86 \%$ of the general aviation accidents involving a fatality. This study reviews certain fundamental tenets and belief systems for each of the major traditional and modern educational philosophies, ideologies and theories. A qualitative determination was made that many of the pedagogies that permeate our educational system have tenets and beliefs can actually exacerbate rather than ameliorate hazardous attitudes. One of the main conclusions of this study is for aviation teachers to constantly examine their personal pedagogical paradigms and remind themselves of four important questions: (a) Do my aviation students have hazardous attitudes? (b) What are those hazardous attitudes? (c) Does my own personal teaching style ameliorate or exacerbate those hazardous attitudes? (d) How can I change or adapt my teaching strategies to better serve the needs of those student pilots suffering from hazardous attitudes?
\end{abstract}

\section{Introduction}

Why do perfectly good pilots crash perfectly good airplanes? This is a question that continues to plague all aviation and especially general aviation. Perhaps the answer to that question can be found in the Aeronautical Decision Making (ADM) process (FAA, 1991). There are 5 hazardous attitudes in aviation adversely affecting ADM and resulting in risk-taking pilot behavior. These hazardous attitudes are antiauthority, impulsivity, invulnerability, macho and resignation.

In 1991, the Federal Aviation Administration (FAA) issued an Advisory Circular (AC) concerning ADM for pilots (FAA, 1991). Since then, there has been an irregular, but steady decline in the general aviation accident rate (NTSB, 2000). It would probably be safe to say that by now most pilots are aware of how hazardous attitudes lead to risk-taking behavior. However, despite the best efforts of the FAA, the National Transportation Safety Board (NTSB), certified flight instructors (CFI), aviation educators, aviation researchers, and professional organizations such as the Aircraft Owners and Pilots Association (AOPA), aviation accidents are still occurring where hazardous attitudes are a factor (Wetmore \& Lu, in-press).

Training in ADM and hazardous attitudes has become a standard part of the curriculum in most professional pilot programs. All Certified Flight Instructors are required to teach their aviation students about how to recognize and avoid hazardous attitudes (FAA, 1999). The FAA requires $A D M$ to be evaluated during practical flight tests (FAA, 2002a; FAA, 2002b; FAA, 2004a). The logic is that good decisions and sound judgments can help to reduce pilot error. For example, here at Central Missouri State University, ADM and hazardous attitude training is included in the following courses: Private Pilot, Instrument Pilot, Commercial Pilot, CFI, and Advanced Flight Crew Management (AFCM). This type of ADM and hazardous attitude education probably occurs in most university aviation programs and in non-collegiate ones as well. Once again, despite all of this ADM education, hazardous attitudes are still a factor in aviation accidents.

The question now becomes: Why are perfectly good pilots, who have been trained in ADM and are aware of the dangers of hazardous attitudes, still crashing perfectly good airplanes? This paper proposes one possible explanation to that question: Some of the basic tenets and beliefs of the educational philosophies, ideologies, and theories (pedagogical paradigms) permeating our educational system can actually exacerbate rather than ameliorate hazardous attitudes.

This paper examines the basic beliefs and tenets of various educational philosophies, ideologies, and theories (pedagogical paradigms) for their potentially ameliorating or exacerbating effects on student pilots with hazardous attitudes. In addition, this study discusses the potentially beneficial or harmful effects of various pedagogical strategies when instructing student pilots with hazardous attitudes. 


\section{Research Questions}

The purpose of this paper is threefold: (a) to present quantitative data on the role of hazardous attitudes in general aviation accidents that involved a fatality; (b) to discuss the basic beliefs and tenets of the various educational philosophies, ideologies, and theories; and, (c) to discuss how pedagogical paradigms can have either a ameliorating or exacerbating effect on student pilots with hazardous attitudes. The research questions which satisfy this purpose are as follows:

1) What are the basic beliefs and tenets of the major educational philosophies, ideologies and theories?

2) How do these educational pedagogies affect student pilots with hazardous attitudes?

3) What pedagogical strategies can an aviation instructor use to ameliorate and not exacerbate the hazardous attitudes likely to be present in many aviation students?

\section{Literature Review \\ Aeronautical Decision-making (ADM)}

Hazardous attitudes can adversely affect a pilot's judgment and thus impact the safety of a flight (FAA, 1991). These hazardous attitudes have been found to be a factor in $86 \%$ of general aviation accidents that involved a fatality (Wetmore \& Lu, in-press). Wiener \& Nagel (1988) found hazardous attitudes to be one of the most important aspects of human factors as applied to the aeronautical decision making process. A hazardous attitude can be defined as the personal motivational predisposition that affects a pilot's ability to make good decisions and sound judgments while flying an airplane (FAA, 1999). Individual personality characteristics and attitudes can have a profound impact on pilots' behavior (Hunter, 2005) and consequently on their decision-making skills (Murray, 1999). Age does not appear to impart wisdom to pilots. Wetmore \& Lu (2005a) found the frequency and occurrence of hazardous attitudes to be randomly distributed among various piloting age groups.

The reduction of hazardous attitudes relies primarily upon the identification of a thought as hazardous and the application of an appropriate antidote (FAA, 1991). Wetmore \& Lu (2005b) found pilot training, as evidenced by the acquisition of certificates and ratings, and flight experience, as indicated by a pilot's total flight time; both significantly reduce displayed hazardous attitudes.

Antiauthority. People with antiauthority reject the authority of public agencies and the opinions of recognized experts. Antiauthority is an attitude found in people who do not like being told what to do (FAA, 1999). It is an attitude where people are resentful towards rules, regulations and procedures. They proceed with an inadvisable course of action despite the rules and training (FAA, 2001). They typically reject the rules and regulations of the Federal Aviation Administration, the directions and instructions given by air traffic control, and the advice of their own flight instructor.

Impulsivity. Pilots with impulsivity act on sudden, spontaneous urges. They feel the need to take immediate action (FAA, 1999). They act recklessly without thinking about the consequences. These pilots do not take the time to consider all options and to select the best course of action (FAA, 2001).

Invulnerability. The invulnerable pilot believes that they are incapable of being injured, damaged or wounded. They think that accidents happen to other people and not to them (FAA, 2001). They are unrealistic pilots who refuse to admit the possibility that they could ever be involved in an accident or an incident. Pilots who think this way are more likely to take unnecessary risks (FAA, 1999).

Macho. Macho is an exaggerated sense of masculinity that stresses attributes such as courage, virility and aggressiveness. Pilots with macho are often trying to impress other people (FAA, 1999). Macho pilots are bold pilots who have something to prove to themselves or others. They are often trying to prove that they are better than other pilots (FAA, 2001).

Resignation. Resignation in aviation is the act of submitting passively to a critical or dangerous flight condition. Pilots with resignation do not see themselves as being able to make a difference in the outcome of a flight (FAA, 1999). A resigned pilot is one who gives up control of the aircraft in a difficult situation. They feel helpless and prefer to relinquish control of the flight's outcome to someone else (FAA, 2001).

\section{Educational Philosophies}

From realism to conservatism, from idealism to liberalism, our current educational systems have been shaped by thousands of years of philosophical debate (Gutek, 2004). To some degree, most aviation teachers and flight instructors employ various elements of traditional or modem pedagogical paradigms promulgated by certain educational philosophies, ideologies, and theories in their teaching methods. Although both flight instructors and their student pilots may not be aware of any particular instructional styles, most are influenced by the educational philosophies, ideologies and theories of their past teachers. This section summarizes the main beliefs and tenets of the major educational philosophies, ideologies and theories.

Idealism. For Idealists (see Table 1), reality is both spiritual and intellectual (Gutek, 2004). The truth lies within each and every one of us. Values are universal and timeless. 
The general takes precedence over the specific. Once a universal principle is established, specific cases should illustrate that general rule. In an idealistic teaching environment, meaningful learning requires meaningful content (Edmonds \& Edmonds, 1997).

Realism. Realists (see Table 1) believe reality to be both physical and mental. They argue that we live in a world of real objects (Gutek, 2004). We gather information about reality by using our senses. The rationality inherent in the human mind organizes and classifies this information. Realist use both inductive and deductive logic. Specific cases can be used to formulate general rules. These general rules can then be used to explain specific circumstances. The realistic educator is seen as a sage on the side, meaning that the teacher's role is to help the student interpret, or see reality (Prawat, 2003).

Pragmatism. Pragmatists (see Table 1) discount the reality of Idealists and Realists. Pragmatists believe ideas or knowledge have value only when they can be proven by experimentation (Gutek, 2004). In addition, knowledge should be beneficial to humanity in some way. Knowledge should advance the quality of life, make our lives more productive, improve safety or solve specific problems. Pragmatists take an activity-based, hands-on, learn-by-doing approach to education (Prawat, 2000).

Existentialism. Existentialists (see Table 1) reject the reality of Idealists and Realists and the purely scientific approaches of the Pragmatists (Gutek, 2004). Existentialists believe individuals create their own reality by selfdiscovery. They believe that the value of an idea or knowledge depends solely on the subjective opinion of the individual. Logic is considered to be transitory and is dependent upon the subject being examined. Existentialist teachers believe in allowing students to choose not only what subject to study, but also how to proceed with their learning (Marlow, 1992).

Postmodernism. Postmodernists (see Table 1) reject the philosophical systems of the past such as Idealism and Realism (Gutek, 2004). Postmodernists also reject the Pragmatists view of explaining reality by using the scientific method. Postmodernists believe that reality is controlled by whoever controls the expression of language. The postmodern teacher encourages students to doubt the grand universal truths and to be skeptical of widely held beliefs not held to scrutiny (Bloland, 2005).

\section{Educational Ideologies}

Classical liberalism. Many of the core beliefs and values helping to shape and form the United States of America have their roots and foundations in classical liberalism (Gutek, 2004). Classical liberals (see Table 2) believe in certain fundamental civil liberties: the inalienable rights of life, liberty and property; a competitive free-market economy; a representative government with majority rule; the freedom from oppressive government controls on the individual; the protection of individual rights through the due process of law; and, an educational system based upon scientific method and scientific reason. The teacher with classical liberal tendencies is likely to stress individualism, freedom, and rationality with their students (Olssen, 2000). Modern liberalism. Modern liberals (see Table 2) believe that people are basically good in nature and individual deficiencies are due to environmental, educational or societal failures (Gutek, 2004). Modern liberals believe education should be flexible and should adapt to the needs of the individual student in particular and to the needs of society as a whole. The use of due process and the following of proper procedures are viewed as methodologies that ensure faimess for all individuals. The modern liberal teacher wants their students to practice an ethical individualism, to be socially aware, to accept rights and duties equally, and to understand that freedom is just as important as equality (Brighouse \& Swift, 2003).

Conservatism. Conservatives (see Table 2) seek to preserve the time-tested, time-honored wisdom of the human race (Gutek, 2004). They hold traditional political, religious, social, and educational institutions to have a fundamental value making those principles worthy of being passed down from generation to generation. Conservatives embrace rugged individualism, respect for the law, high moral and ethical standards, personal freedom and economic opportunity. Modern conservative teachers endorse certain educational tenets: students should be able to achieve definable learning outcomes; curriculum content should be standardized; the free market should be used to delineate educational choices; and, there should be more community input into the educational process (Loxley \& Thomas, 2001).

Liberation pedagogy. Liberation pedagogy is an ideology designed to free people from oppression (Gutek, 2004). Liberationists (see Table 2) want to raise the consciousness of people so they are aware of the social, political, economic and cultural conditions that have led to their domination by ruling groups of elitists. Liberationists emphasis critical thinking and encourage people to base their actions on the situational analysis generated by critical thinking. Some liberationists separate schooling, which provides information, from education, which involves interpretation and critical thinking (Hakken, 1983). 


\section{Educational Theories}

Essentialism. According to Gutek (2004), essentialists believe that certain basic ideas, skills and bodies of knowledge are essential to human culture and civilization (see Table 3). These basic ideas, skills and knowledge are indispensable to human society. The role of education is to transmit these fundamental ideas, skills and knowledge from one generation to the next. Schooling is seen as an educational ladder that logically and deliberately takes students from the simple to the complex. The essentialist wants their students to be productive members of society. They teach their students how to survive, how to succeed, and how not to be a burden upon others (Gaudelli, 2002).

Perennialism. Perennialists (see Table 3) believe people enjoy and share common characteristics that define them as human beings (Gutek, 2004). The most common of these attributes is rationality. Perennialists base their values upon enduring, universal truths which bridge the past, present and future. They believe that rationality, together with these universally recognizable truths, should be used to organize and prioritize society. The perennialist educator believes: human nature tends to be bad; harmful cultural influences are endemic to the learning environment; value systems originate in the intellect; and, historical values are the best hope for the future (Gaudelli, 2002).

Progressivism. The fundamental belief of progressives holds everything affecting the human condition, such as society, education, politics, the economy, etc., can be, and should be, improved (Gutek, 2004). Progressives (see Table 3 ) believe education should address the emotional, physical, social, and intellectual concerns as well as the traditional academic concerns of the student. Progressives favor educational processes that stimulate creativity and imagination and are opposed to inflexible and rigid curricula. The modern progressive believe teachers should: focus on the needs of the student; and, create a student empowering environment (Silcock, 1996).

Critical theory. Critical theorists (see Table 3) believe in the meticulous, analytical assessment of the political, cultural, social, and educational conditions shaping and influencing society (Gutek, 2004). They believe that the prevalent social, educational and political structures are basically, unequal, unfair, unjust and exploitive. Critical theorists seek to bring about change in society by critically examining the power structures, exposing the exploitation, and then empowering the marginalized groups. The critical theorist, as teacher, seeks to involve their students in an emotional, critical theorizing process that ultimately reveals the true nature of reality (Callahan, 2004).

\section{Research Methodology}

A comprehensive literature review of the major traditional and modern educational philosophies, ideologies and theories was conducted to establish the fundamental tenets and belief systems for each. In addition, a comprehensive review of the aeronautical decision-making literature was performed to establish the characteristics and attributes of hazardous attitudes. The pedagogical paradigms were then arranged in a crosstabulation format opposite each of the 5 hazardous attitudes classifications. A subjective determination was made on whether a particular teaching tenet or educational belief would ameliorate, exacerbate, or have no effect on hazardous attitudes suffered by a student pilot.

\section{Results \& Discussion}

The relationships between the various educational pedagogies and hazardous attitudes are shown in Table 1, 2 and 3. The main beliefs and tenets for each of the educational philosophies, ideologies, and theories are shown in the rows of the tables. The columns contain the 5 hazardous attitudes. These tables depicts a subjective determination of whether or not a particular pedagogical paradigm would be ameliorating, exacerbating or neutral for a student pilot suffering from a particular hazardous attitude.

The discussions below illustrate how certain educational pedagogies listed in Tables 1,2 and 3 could be used as teaching strategies to benefit a student pilot suffering from a specific hazardous attitude and how other education pedagogies could have a detrimental affect on that same student.

\section{Teaching student pilots with antiauthority}

The Federal Aviation Administration's advice for pilots with antiauthority is to follow the rules, they are usually right (FAA, 1999). A pragmatic approach might be well suited for student pilots with antiauthority (see Table 1). Pragmatists believe in that knowledge which can be proven by experience or experimentation (Gutek, 2004). A pragmatic flight instructor could use aircraft accident case histories to show how not following the rules can lead to aircraft crashes.

A critical theory approach to a student with antiauthority might be a bad idea (see Table 3). Part of the philosophy of a critical theorist is to question the current power structure (Gutek, 2004). Encouraging a student pilot to question the motives behind the rules and regulations of the Federal Aviation Administration would be counterproductive and could lead to regulatory violations 
and aircraft accidents.

Students with antiauthority should be taught to follow the rules. Teaching these students to doubt the rules (from post-modernism in Table 1), or reality is defined by the student (from existentialism in Table 1), or societal rules should be subjected to critical analysis (from critical theory in Table 3) could encourage these students to violate the Federal Aviation Regulations when it suited them and thus make their antiauthority worse. On the other hand, a teaching style emphasizing that the rules are based on rationality (from perennialism in Table 3 ), or rules are beneficial (from pragmatism in Table 1), or obeying the rules is a moral and ethical obligation (from conservatism in Table 2), could promote rule-abiding pilot behavior and help alleviate their antiauthority.

\section{Teaching student pilots with impulsivity}

A flight instructor's responsibility with an impulsive student is to find a way to get that student to stop and think about the consequences of their actions (FAA, 1999). A realistic approach might be appropriate for the impulsive student (see Table 1). Realists use both inductive and deductive reasoning to go from the specific to the general and back to the specific (Gutek, 2004). A realistic flight instructor could tell a student it is tempting to have fun by flying low and "buzzing" people on the ground (the specific). However, down close to the ground there are a lot of towers, power lines and other obstacles to flight (the general). As a result, a lot of people have crashed airplanes while flying close to the ground (the specific).

The existentialist flight instructor might have problems with an impulsive student pilot (see Table 1). Existentialists believe people create their own realities and the value of an idea is subjective (Gutek, 2004). Following this logic, the determination of the training value of flying at tree-top level is solely in the purview of the pilot at the controls of the airplane, regardless of the dangers.

Students with impulsivity should be taught to think before acting. Teaching these students that they have to learn by doing (from pragmatism in Table 1), or logic is subjective and not objective (from existentialism in Table 1), or reality is controlled by the user (from post-modernism in Table 1), could fail to rein in the impulsive behavior. Conversely, teaching students to be logical and deliberate (from essentialism in Table 3), or to use rational thought processes (from classical liberalism in Table 2), or to use general rules to explain why specific behavior is dangerous (from realism in Table 1), could help these students to think before acting.
Teaching student pilots with invulnerability

The Federal Aviation Administration's suggested antidote for invulnerability is for the pilot to admit it could happen to them (FAA, 1999). A perennialistic approach might find some success with the student pilot who suffers from invulnerability (see Table 3). Perennialists believe in rationality and universal truths (Gutek, 2004). A universal truth in aviation is that pilots who take risks are often involved in fatal accidents. Everyone knows that the Wright brothers were the first to fly. The invulnerable pilot needs to be reminded of the large number of people who died trying to be the first to fly. Everyone knows that Charles Lindbergh was the first pilot to make a solo crossing of the Atlantic. The invulnerable pilot needs to be reminded of how many pilots died trying to be the first to cross the Atlantic. Flight Instructors need to teach how it is completely irrational to think that risk-taking does not lead to accidents.

A liberationist teaching philosophy might not be a good choice for a flight instructor teaching a student who has an invulnerable attitude (see Table 2). Liberationists want people to use critical thinking to challenge the status quo (Gutek, 2004). While critical thinking is generally accepted as a good thing in aviation, challenging commonly accepted beliefs concerning safety could be bad. For example, with practice a pilot can learn how to spin an airplane and recover while losing only 500 feet of altitude. The Federal Aviation Administration (FAA, 2004b), recommends spins to be performed at an altitude that will allow a full recovery at an altitude of 1,500 feet above ground level. A student pilot with invulnerability, coached in the inappropriate use of critical thinking, might see this difference in ability versus regulation as a green light to take unnecessary risks.

Students with invulnerability should be taught to understand that aviation accidents can happen to them. Teaching these students that knowledge must be proven by experiment (from pragmatism in Table 1), or students should guide their own learning (from existentialism in Table 1), or reality is controlled by whoever describes the situation (from post-modernism in Table 1), could encourage invulnerable behavior. Teaching students with invulnerability that it is a universal and enduring truth that taking risks is dangerous (from idealism in Table 1), or it is time-tested wisdom that risk-taking leads to accidents (from conservatism in Table 2), or risk-taking will not lead to success or survival (from essentialism Table 3 ), could help these students overcome feelings of invulnerability. 


\section{Teaching student pilots with macho}

To counteract macho, student pilots need to be aware of the fact that taking unnecessary risks in an attempt to impress other people is very foolish (FAA, 1999). The need to impress other people has been linked inferiority complexes and low self-esteem (Muchinsky, 2003). A conservative approach might work well with a macho pilot (see Table 2). Conservatism stresses the value of being a rugged individual and of having a personal code of ethics (Gutek, 2004). A flight instructor could encourage and reinforce this type of self-image as a means to bolster selfesteem. The logic in this approach: A rugged individual with a personal code of ethics should feel very little need to impress others with risky demonstrations of superior flying skill.

Postmodernists (see Table 1) advocate the belief in people taking an analytical approach to what is considered a logical or illogical action based on who is providing the basis for that determination. Postmodernists are especially wary of those who use logic to generalize rules of behavior and then apply them to specific categories of people (Gutek, 2004). This might not be the best approach for a student pilot that suffers from macho. A macho pilot could use this reasoning to justify their risk-taking actions. A macho pilot could rationalize to themselves that the risks they took were acceptable because of their superior flying skills.

Macho student pilots need to be taught that taking unnecessary risks is foolish behavior. With these students empowerment (from progressivism in Table 3), or rugged individualism (from conservatism in Table 2), or the stressing of individual freedom (from classical liberalism in Table 2), would do little to counteract the personal motivations leading to a macho attitude. Teaching macho student pilots to apply critical thinking to their behavior (from critical theory in Table 3), or helping them to "see" the reality of their reckless actions (from realism in Table 1), or by clarifying basic safety skills as "essential" to their aviation education (from essentialism in Table 3), could help student pilots overcome their macho tendencies.

Teaching student pilots with resignation

To counteract resignation, pilots need to overcome their feelings of helplessness and believe they can make a positive difference regarding the outcome of a particularly difficult flight (FAA, 1999). The classical liberalism focus on the rights and power of the individual might be a good approach for a pilot with resignation (see Table 2). The classical liberal believes that the individual comes first and each individual must assert themselves (Gutek, 2004). A flight instructor could use this concept of individual assertion to encourage the resigned student pilot to take an active responsibility for the safe outcome of every flight regardless of the difficulties or the dangers or the pressures.

There is a tendency in modern liberalism (see Table 2) to place the blame for an individual's failure on their environment (society, politics, culture, economics, etc.) (Gutek, 2004). This projection of blame could be contrary to the best interests of a pilot suffering from resignation. The antidote (FAA, 1999) for resignation is the belief that the pilot can make a difference. Pilots with resignation need to take more responsibility for the outcome of a flight, not less. Being able to blame a pilot's shortcomings on the environment in which they were raised is small consolation to the passengers of an accident aircraft.

Student pilots suffering from resignation need to be made to feel that they can make a difference. Teaching these students that their deficiencies are due to their environment (from modern liberalism in Table 2), or they should doubt prescribed procedures (from post-modernism in Table 1), or the reality of a situation is subjective (from existentialism in Table 1), would do little to relieve student pilots of feelings of hopelessness. Teachers with students that have resignation would do well to cultivate a sense of rugged individualism (from conservatism in Table 2), or to find ways to empower the student (from progressivism in Table 3 ), or to use situational analysis to determine their best course of action during a critical flight event (from liberation pedagogy in Table 2).

\section{Conclusions}

Few would argue that the introduction of $A D M$ in 1991 (FAA, 1991) and its resultant effect on flight training (FAA, 1999: FAA, 2001; FAA, 2004B) was not a contributing factor to the steady decline of general aviation accidents since that time (NTSB, 2000). Due to the efforts of the FAA and others, the teaching of ADM and hazardous attitudes has become a standard part of the curriculum at most flight schools. However, despite this emphasis on ADM training, hazardous attitudes are still a factor in $86 \%$ of general aviation accidents that involved a fatality (Wetmore \& Lu, in-press).

This brings us back to our original question: Why are perfectly good pilots, who have been trained in ADM and are aware of the dangers of hazardous attitudes, still crashing perfectly good airplanes? The answer to this question may be that certain tenets and beliefs of the educational philosophies, ideologies, and theories permeating our educational system can actually exacerbate rather than ameliorate hazardous attitudes (see Tables 1, 2 and 3). Whether a flight instructor realizes it or not, most 
teachers have been influenced to some degree by these pedagogical paradigms.

The Aviation Instructor's Handbook advises aviation instructors to act as practical psychologists when teaching student pilots (FAA, 1999). As such, one of the responsibilities of the aviation instructor is to recognize and respond to any potentially hazardous attitudes in their students. To meet that responsibility, aviation teachers need to carefully pick and choose those particular tenets and beliefs from among the educational pedagogies (instructional methods and teaching styles) that will help to alleviate, and certainly not exacerbate, student pilot hazardous attitudes.

Therefore, the final conclusion of this paper is that aviation teachers must constantly examine their personal pedagogical paradigms and remind themselves of four important questions: (a) Do my aviation students have hazardous attitudes? (b) What are those hazardous attitudes? (c) Does my own personal teaching style ameliorate or exacerbate those hazardous attitudes? and, (d) How can I change or adapt my teaching strategies to better serve the needs of those student pilots suffering from hazardous attitudes?

\section{Future Study}

The prospect of subjecting the qualitative hypotheses set forth in this paper to an objective, quantitative human subjects study would be both fascinating and problematic. The teaching styles of most aviation educators and flight instructors are likely to be an amalgamation of various educational philosophies, ideologies, and theories. It would be interesting to see which tenets and beliefs are most common among these teachers. Most student pilots probably have multiple hazardous attitudes in various combinations and degrees of severity. It would be interesting to see which hazardous attitudes, and combinations thereof, are the most common among student pilots. And finally, it would be interesting to investigate and measure the effects of the various educational pedagogies on these assorted hazardous attitudes.

The benefits of such a study are clear. The difficulties of such an investigation are just as obvious. With the vast multitude of possible instructor-student combinations of teaching styles and hazardous attitudes, the tasks of formulating hypothetical constructs and designing the research methods would be daunting. Just as daunting would be the task of sorting out the independent, dependent, confounding, and moderating variables. The main challenge would be to take these multiple combinations of variables and assemble statistically significant sample sizes while at the same time being able to adequately assess internal and external validity and reliability issues. $\rightarrow$

Michael Wetmore, M.S., University of North Dakota, is an assistant professor in the Department of Aviation, University of Central Missouri. His teaching and research interests include aviation education, crew resource management, aeronautical decision making, aviation safety, and flight training. In addition, he is an active flight instructor.

Chien-tsung Lu, Ph.D., University of Nebraska, is an assistant professor in the Department of Aviation, University of Central Missouri. His teaching and research interests include air transportation policy, aviation law, aviation safety, airline operations, and maintenance management.

William Caldwell, Ph.D., Southem Illinois University, is an associate professor in the Department of Aviation, University of Central Missouri. His teaching and research interests include aviation safety, aviation education, crew resource management, flight training and airline operations. 


\section{References}

Bloland, H.G. (2005). Whatever happened to postmodernism in higher education?: No requiem in the new millennium. The Journal of Higher Education, 76(2), 121-151.

Brighouse, H., \& Swift, A. (2003). Defending liberalism in education theory. Journal of Education Policy, 18(4), 355-373.

Callahan, J. L. (2004). Breaking the cult of rationality: Mindful awareness of emotion in the critical theory classroom. New Directions for Adult and Continuing Education, 102, 75-83.

Edmonds, C. D., \& Edmonds, T. P. (1997). Educational idealism: One more reason to stress the perpetual inventory system in classroom instruction. Journal of Education for Business, 72(4), 217-221.

Federal Aviation Administration. (1991). Aeronautical decision making. (FAA Advisory Circular 60-22). Author.

Federal Aviation Administration. (1999). Aviation instructor's handbook (FAA-H-8083-9). Author.

Federal Aviation Administration. (2001). Instrument flying handbook (FAA-H-8083-15). Author.

Federal Aviation Administration. (2002a). Private pilot practical test standards (FAA-S-8081-14AS). Author.

Federal Aviation Administration. (2002a). Commercial pilot practical test standards (FAA-S-8081-12B). Author.

Federal Aviation Administration. (2004a). Instrument rating practical test standards (FAA-S-8081-4D). Author.

Federal Aviation Administration. (2004b). Airplane flying handbook (FAA-H-8083-3A). Author.

Fallucco, S. J. (2002). Aircraft command techniques. Burlington, VT: Ashgate.

Gaudelli, W. (2002). U.S. kids don't know U.S. history: The NAEP study, perspectives, and presuppositions. The Social Studies, 93(5), 197-201.

Gutek, G. (2004). Philosophical and ideological voices in education. Boston: Pearson Education, Inc.

Hakken, D. (1983). Impacts of liberation pedagogy: The case of workers' education. Journal of Education, 165(1), 113-130.

Hunter, D. R. (2005). Measurement of hazardous attitudes among pilots. The International Journal of Aviation Psychology, $15(1), 23-43$.

Loxley, A., \& Thomas, G. (2001). Neo-conservatives, neo-liberals, the new left and inclusion: Stirring the pot. Cambridge Journal of Education, 31(3), 291-301.

Marlow, E. (1992). Philosophy of education and the mathematics curriculum. Journal of Instructional Psychology, 19(4), 236-241.

Muchinsky, P. M. (2003). Psychology applied to work ( $7^{\text {th }}$ Ed.). Belmont, CA: Wadsworth/Thomson Learning.

Murray, S. R. (1999). FACE: Fear of loss of face and the five hazardous attitudes concept. The International Journal of Aviation Psychology, 9(4), 403-411. 
National Transportation Safety Board. (2000). Annual review of aircraft accident data, U.S. general aviation, calendar year 2000. Author.

National Transportation Safety Board. (2005). Data and information products. Aviation accident database. Retrieved July 19, 2005, from http://www.ntsb.gov/ntsb/query.asp.

Olssen, M. (2000). Ethical liberalism, education and the 'New Right'. Journal of Educational Policy, 15(5), 481-508.

Prawat, R. S. (2000). The two faces of Deweyan pragmatism: Inductionism versus social constructivism. Teachers College Record, 102(4), 805-840.

Prawat, R. S. (2003). The nominalism versus realism debate: Toward a philosophical rather than a political resolution. Educational Theory, 53(3), 275-311.

Silcock, P. (1996). Three principles for a new progressivism. Oxford Review of Education. 22(2), 199-217.

Wetmore, M. J., \& Lu, C-t. (in-press). The effects of hazardous attitudes on crew resource management skills. International Journal of Applied Aviation Studies.

Wetmore, M. J., \& Lu, C-t. (2005a). The effects of pilot age on aeronautical decision making and crew resource management skills. White paper. Central Missouri State University.

Wetmore, M. J., \& Lu, C-t. (2005b). Reducing hazardous attitudes: the effects of pilot certification and flight experience. White paper. Central Missouri State University.

Wiener, E.L., \& Nagel, D.C. (1988). Human factors in aviation. San Diego, CA: Academic Press, Inc. 
Table 1: Educational Philosophies and Hazardous Attitudes

\begin{tabular}{|c|c|c|c|c|c|}
\hline \multirow{2}{*}{$\begin{array}{l}\text { Pedagogical Tenets \& Beliefs } \\
\underline{\text { Idealism }}\end{array}$} & \multicolumn{5}{|c|}{ Potential Pedagogical Effect on Hazardous Attitudes } \\
\hline & $\mathrm{Aa}^{2}$ & $\operatorname{Imp}^{2}$ & $\ln v^{2}$ & $\mathrm{Ma}^{2}$ & $\operatorname{Res}^{2}$ \\
\hline Values are universal and enduring. & A & A & $\mathrm{A}$ & $\mathrm{A}$ & A \\
\hline Specific cases illustrate the general rule. & A & $\mathbf{A}$ & A & A & A \\
\hline $\begin{array}{l}\text { Meaningful content results in meaningful learning. } \\
\text { Realism }\end{array}$ & $\mathbf{A}$ & A & $\mathbf{A}$ & $\mathbf{A}$ & A \\
\hline The senses are used to define reality. & A & A & A & A & A \\
\hline General rules are used to explain specific cases. & A & A & A & A & A \\
\hline $\begin{array}{l}\text { Teachers help students to see reality. } \\
\text { Pragmatism }\end{array}$ & $\mathbf{A}$ & $\mathbf{A}$ & A & A & $\mathbf{A}$ \\
\hline Knowledge must be proven by experiment. & $\mathrm{E}$ & $\mathrm{E}$ & $\mathrm{E}$ & $\mathrm{E}$ & $\mathrm{E}$ \\
\hline Knowledge must be beneficial to the student. & $\bar{A}$ & $\bar{A}$ & $\mathbf{A}$ & A & $\mathrm{E}$ \\
\hline $\begin{array}{l}\text { Students learn by doing not by listening. } \\
\text { Existenialism }\end{array}$ & A & $\mathrm{E}$ & $\mathrm{E}$ & $\mathrm{E}$ & $\mathbf{N}$ \\
\hline Reality is best defined by the student. & $\mathrm{E}$ & $\mathrm{E}$ & E & $\mathrm{E}$ & $\mathrm{E}$ \\
\hline Logic is subjective and not objective. & $\mathrm{E}$ & $\mathrm{E}$ & $\mathrm{E}$ & $\mathrm{E}$ & $E$ \\
\hline $\begin{array}{l}\text { Students guide their own learning. } \\
\text { Post Modernism }\end{array}$ & $\mathrm{E}$ & $\mathrm{E}$ & $\mathrm{E}$ & $\mathrm{E}$ & $\mathrm{N}$ \\
\hline Reality cannot be defined by experiment. & $\mathbf{E}$ & $\mathbf{N}$ & $\mathbf{N}$ & $\mathbf{E}$ & $\mathrm{N}$ \\
\hline Reality is controlled by language. & $\mathrm{E}$ & $\mathrm{E}$ & $\mathrm{E}$ & $\mathrm{E}$ & $\mathbf{N}$ \\
\hline Teachers should encourage students to doubt. & $\mathbf{E}$ & $\mathbf{E}$ & $\mathbf{E}$ & $\mathrm{E}$ & $\mathrm{E}$ \\
\hline
\end{tabular}


Table 2: Educational Ideologies and Hazardous Attitudes

Pedagogical Tenets \& Beliefs

\section{Classical Liberalism}

Believe in the scientific method.

Stress individual rights and freedom.

Teachers should emphasize rationality with students.

Modern Liberalism

Student deficiencies are due to societal environment.

Teachers should stress social awareness.

Education should adapt to the needs of the individual student.

Conservatism

Preservation of time-tested wisdom.

Cultivation of rugged individualism.

Emphasis on high moral and ethical standards.

Liberation Pedagogy

Awareness of social and cultural conditions.

Actions based on situational analysis.

Emphasis on critical thinking.
Potential Pedagogical Effect on Hazardous Attitudes ${ }^{1}$

\begin{tabular}{|c|c|c|c|c|}
\hline $\mathrm{Aa}^{2}$ & $\operatorname{Im} p^{2}$ & Inv ${ }^{2}$ & $\mathrm{Ma}^{2}$ & $\operatorname{Res}^{2}$ \\
\hline A & A & $\mathrm{A}$ & $\mathrm{A}$ & $\mathrm{A}$ \\
\hline $\mathbf{E}$ & $\mathbf{A}$ & $\dot{\mathbf{A}}$ & $\mathrm{E}$ & A \\
\hline A & A & A & A & A \\
\hline $\mathrm{E}$ & $\mathbf{N}$ & $\mathbf{N}$ & $\mathbf{N}$ & $E$ \\
\hline $\mathbf{N}$ & $\mathbf{N}$ & $\mathbf{N}$ & $\mathbf{N}$ & $\mathrm{N}$ \\
\hline A & A & A & A & A \\
\hline A & $\mathbf{A}$ & A & $\mathbf{A}$ & A \\
\hline $\mathrm{E}$ & $\mathrm{E}$ & $\mathrm{E}$ & $E$ & A \\
\hline A & A & A & A & A \\
\hline$E$ & $\mathrm{~N}$ & $\mathbf{N}$ & A & $\mathrm{N}$ \\
\hline A & A & A & $\mathbf{A}$ & A \\
\hline $\mathrm{E}$ & $\mathbf{A}$ & A & $\mathbf{A}$ & A \\
\hline
\end{tabular}

(1) Potential Effect: Ameliorating (A); Neutral (N); or, Exacerbating (E)

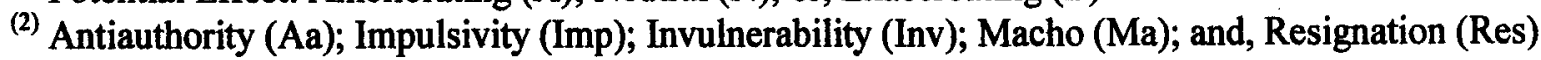


Table 3: Educational Theories and Hazardous Attitudes

\section{Pedagogical Tenets \& Beliefs}

\section{Essentialism}

Basic skills are essential to education.

Education is logical and deliberate.

Students should be taught how to survive and succeed.

Perennialism

The truth is universal and enduring.

Historical values are the best hope for the future.

Education should be based on rationality.

Progressivism

Education should stimulate the imagination.

Teachers should focus on the needs of the student.

Teachers should empower their students.

Critical Theory

Analytical assessment of societal conditions.

Reality is ultimately revealed by critical analysis.

Teachers emphasize the critical thinking process.
Potential Pedagogical Effect on Hazardous Attitudes ${ }^{1}$

\begin{tabular}{|c|c|c|c|c|}
\hline $\mathrm{Aa}^{2}$ & $\operatorname{Im} p^{2}$ & Inv $^{2}$ & $\mathrm{Ma}^{2}$ & $\operatorname{Res}^{2}$ \\
\hline $\mathbf{A}$ & $\mathbf{A}$ & A & $\mathrm{A}$ & $\mathrm{A}$ \\
\hline A & A & A & A & $\mathbf{A}$ \\
\hline $\mathbf{A}$ & $\mathbf{A}$ & A & A & $\mathbf{A}$ \\
\hline A & A & A & A & A \\
\hline A & A & A & A & A \\
\hline A & A & A & A & A \\
\hline A & A & A & A & A \\
\hline A & A & A & A & A \\
\hline $\mathrm{E}$ & $\mathrm{N}$ & $\mathrm{N}$ & $\mathrm{E}$ & A \\
\hline $\mathrm{E}$ & $\mathbf{N}$ & $\mathrm{N}$ & $\mathrm{N}$ & $\mathrm{N}$ \\
\hline E & A & A & $\mathrm{N}$ & A \\
\hline E & A & A & A & A \\
\hline
\end{tabular}

(1) Potential Effect: Ameliorating (A); Neutral (N); or, Exacerbating (E)

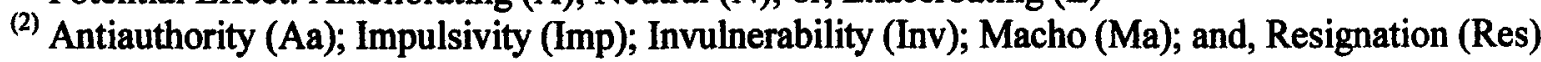

